\title{
Nitrogen-starvation-induced chlorosis in Synechococcus PCC 7942 : adaptation to long-term survival
}

\author{
Margit Görl, Jörg Sauer, Tina Baier and Karl Forchhammer
}

Lehrstuhl für

Mikrobiologie der Universität München, Maria-Ward-Straße 1a, D-80638 München, Germany
Author for correspondence: Karl Forchhammer. Tel: +4989179198 64. Fax: +498917919862. e-mail: KForch@lrz.uni-muenchen.de

Keywords: cyanobacteria, dormant state, phycobiliproteins, photosynthesis, proteolysis

\section{INTRODUCTION}

Cyanobacteria are one of the most widespread groups of Gram-negative bacteria. They display considerable morphological diversity and unusual capacities for cellular differentiation, while their basic metabolism is fairly uniform. Cyanobacteria are capable of photoautotrophic growth, performing oxygenic photosynthesis, similar to that of eukaryotic algae and plants. Moreover, they employ highly efficient mechanisms to adapt to changes in ambient conditions (for a review see Tandeau de Marsac \& Houmard, 1993). One of the essential requirements to survive in natural environments is the ability to withstand nutrient limitation or even deprivation. In the absence of combined nitrogen sources, diazotrophic cyanobacteria avoid nitrogen deficiency by fixing molecular nitrogen. Non-diazotrophic strains respond to nitrogen deprivation by degrading

Abbreviations: chl, chlorophyll; DAPI, 4',6'-diamidino-2-phenylindole; DCMU, 3-(3,4-dichlorophenyl)-1,1-dimethylurea; PC, phycocyanin; PFD, photon flux density; PS, photosystem. their photosynthetic pigments, resulting in a change in the colour of cultures from blue-green to yellow, a process known as chlorosis (Allen \& Smith, 1969; Lau et al., 1977). Chlorosis also occurs upon starvation for other essential nutrients, although the chlorotic response shows subtle differences at the cellular level, depending on the limiting nutrient (Collier \& Grossman, 1992; Wanner et al., 1986).

Of the different chlorotic reactions, that induced by nitrogen starvation has been most extensively studied. Most investigations have focused on the degradation of the major light-harvesting complexes, the phycobilisomes, which proceeds in an ordered manner (reviewed by Grossman et al., 1994). A small polypeptide (NblA) was identified that triggers the proteolytic degradation of phycobiliproteins; however, its precise function is still unknown (Collier \& Grossman, 1994). In various studies, the time course and extent of phycocyanin (PC) degradation has varied from only $50 \%$ degradation of PC per volume of culture within $60 \mathrm{~h}$ (Lau et al., 1977) to $90 \%$ degradation within $9 \mathrm{~h}$ (Wanner et al., 1986). Wanner et al. (1986) showed that the decay of PC was 
accompanied by a dramatic degradation of chlorophyll $a$ (chl $a)$, whereas in other investigations the chl $a$ content during chlorosis remained constant (Allen \& Smith, 1969) or decreased only slightly (Collier \& Grossman, 1992). However, these studies were performed with cells grown under different $\mathrm{CO}_{2}$ concentrations and illumination intensities. Even different experimental procedures of induction of combined nitrogen deprivation (step-down) could have contributed to differences in the results. Nitrogen step-down was performed by one of two methods. Nitrate-grown cells were inoculated into a medium that contained limiting amounts of nitrate. The cells proliferated until the nitrogen source was exhausted and then started to bleach (Allen \& Smith, 1969; Wanner et al., 1986). Alternatively, cells were harvested in the exponential growth phase by centrifugation, washed and resuspended in a medium lacking a combined nitrogen source. This procedure allows a better definition of the onset of nitrogen starvation (Lau et al., 1977; Collier \& Grossman, 1992). Here, the cells are able to divide once before growth ceases. Upon nitrogen starvation, cells accumulate products of photosynthesis that are stored as glycogen (Allen, 1984); however, a thermophilic Synechococcus strain was described that accumulates up to $27 \%$ poly- $\beta$-hydroxybutyrate per dry weight (Miyake et al., 1997).

Within $1-3 \mathrm{~d}$ of the onset of nitrogen starvation, cyanobacteria are able to initiate growth upon a shift to nutrient-replete conditions (Allen, 1984, Wanner et al., 1986). A decline of the cellular chl a content following the initial chlorosis reaction has often been interpreted as an irreversible decay of cell viability (Tandeau de Marsac \& Houmard, 1993). However, the capacity to survive longer starvation periods has not been investigated. Prolonged starvation of unicellular microorganisms often leads to cellular differentiation, which may result in the generation of dormant spores, as is found in many Gram-positive bacteria. In contrast, in various non-sporulating heterotrophic bacteria, a small subpopulation of non-dormant survivors differentiates, which may remain viable for years (Zambrano \& Kolter, 1996; Watson et al., 1998). Here we demonstrate that the photoautotrophic organism Synechococcus PCC 7942 survives prolonged periods of nitrogen deprivation, by differentiating into non-pigmented cells that show characteristics of a dormant state.

\section{METHODS}

Organism and culture conditions. Synechococcus sp. strain PCC 7942, small plasmid cured (Kuhlemeier et al., 1983), hereafter designated Synechococcus PCC 7942, was grown photoautotrophically in BG-11 ${ }^{\mathrm{N}}$ medium (Rippka, 1988) that was modified as follows: ferric ammonium citrate was replaced by ferric citrate and the medium was buffered to $\mathrm{pH} 7.8$ with $20 \mathrm{mM}$ HEPES. Medium lacking combined nitrogen $\left(\mathrm{BG}-11^{\circ}\right)$ corresponded to $\mathrm{BG}-11^{\mathrm{N}}$ medium, but $\mathrm{NaNO}_{3}$ was replaced by the same molarity of $\mathrm{NaCl}$ $(17.6 \mathrm{mM})$. Stock cultures $(40 \mathrm{ml})$ in $100 \mathrm{ml}$ Erlenmeyer flasks were incubated at $30^{\circ} \mathrm{C}$ without additional aeration and illuminated with a photosynthetic photon flux density (PFD) of approximately $10 \mu \mathrm{mol}$ photons $\mathrm{m}^{-2} \mathrm{~s}^{-1}$ from fluorescent lamps. The photosynthetically active radiation was determined with a quantum sensor (LI-190SA, LI-COR). For starvation experiments, cultures were grown in $200 \mathrm{ml}$ BG- $11^{\mathrm{N}}$ in one litre Erlenmeyer flasks with magnetic stirring and aerated either with air, or with air supplemented with $2 \% \quad \mathrm{CO}_{2}$; standard illumination conditions at a PFD of $50-60 \mu \mathrm{mol} \mathrm{m}{ }^{-2} \mathrm{~s}^{-1}$ were provided from fluorescent lamps. For the determination of numbers of c.f.u., appropriate dilutions of liquid cultures were plated on $\mathrm{BG}-11^{\mathrm{N}}$ medium solidified by the addition of $0.9 \%(\mathrm{w} / \mathrm{v})$ of Gel-Rite (Roth) and incubated at $30^{\circ} \mathrm{C}$ with a PFD of $30 \mu \mathrm{mol} \mathrm{m} \mathrm{m}^{-2} \mathrm{~s}^{-1}$.

Initiation of nitrogen deprivation. A $100 \mathrm{ml}$ volume of exponentially growing cells was harvested at $\mathrm{OD}_{750} 0.5$ by filtering the culture through a $0.45 \mu \mathrm{m}$ PVDF membrane filter (Millipore, type HVLP) in a transparent filtration unit under constant illumination $\left(55 \mu \mathrm{mol} \mathrm{m}{ }^{-2} \mathrm{~s}^{-1}\right)$. Care was taken not to dry out the cell layer on the filter. The cell layer was washed

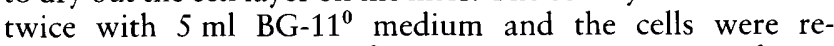
suspended in $200 \mathrm{ml} \mathrm{BG}-11^{\circ}$ medium to give an $\mathrm{OD}_{750}$ of $0 \cdot 25$; the incubation was continued in one litre Erlenmeyer flasks under the same growth conditions. The amount of evaporated water was determined daily by weighing and the corresponding volume of distilled sterile water was added to the culture.

Regeneration experiments. To assay the regeneration of photosynthetic pigments in individual cells, $5 \mathrm{ml}$ samples were withdrawn from nitrogen-deprived cultures into sterile $25 \mathrm{ml}$ flasks, supplemented with $17.6 \mathrm{mM}$ sodium nitrate and $25 \mu \mathrm{g}$ aztreonam ml $\mathrm{m}^{-1}$, and incubated at a PFD of $40 \mu \mathrm{mol}$ photons $\mathrm{m}^{-2} \mathrm{~s}^{-1}$. Addition of aztreonam, an inhibitor of cell septation, was repeated after 3 and $5 \mathrm{~d}$. Regeneration of pigments was observed by epifluorescence microscopy. To concomitantly visualize the non-regenerated cells, cells were stained with DAPI (4',6'-diamino-2-phenylindole).

Pigment and glycogen determination. PC, $\mathrm{chl} a$ and glycogen were determined as previously described (Forchhammer \& Tandeau de Marsac, 1995). The unit for PC determination (net $A_{620}$ ) results from the difference spectrum of cultures before and after heating to $75^{\circ} \mathrm{C}$ for $8 \mathrm{~min}$ and is calculated according to the following equation : net $A_{620}=\left[A_{620}-A_{750}\right.$ (unheated) $]-\left[A_{620}-A_{750}\right.$ (heated) $]$ (Collier \& Grossman, 1992).

Measurement of photosynthetic activities. Photosynthetic oxygen evolution was measured using a Clark-type oxygen electrode (Hansatech DW1) as described by Walker (1987). Light was provided from a high-intensity white-light source (Hansatech LS2) and light intensity was adjusted using neutral density filters. Oxygen consumption or evolution in $2 \mathrm{ml}$ samples was measured at the following PFDs: 0, 7, 12, 24, 82 and $3000 \mu \mathrm{mol} \mathrm{m}^{-2} \mathrm{~s}^{-1}$. PS II activity was determined in intact cells by measuring oxygen evolution in a Hill reaction after addition of $0.5 \mathrm{mM}$ ferricyanide and $0.1 \mathrm{mM}$ benzoquinone using saturating actinic light of $3000 \mu \mathrm{mol} \mathrm{m}^{-2} \mathrm{~s}^{-1}$ (Shen et al., 1993). PS I activity was estimated by measuring the lightinduced oxygen uptake (Mehler reaction) in permeabilized cells using the protocol of Hauska (1980), adapted for use with cyanobacteria. To $4 \mathrm{ml}$ cell suspension (with an $\mathrm{OD}_{750}$ of $0.25-0.5), 20 \mu \mathrm{l} 1 \mathrm{M}$ HEPES $\mathrm{pH} \mathrm{8.0,20 \mu l} 5 \mathrm{M} \mathrm{NaCl}$,

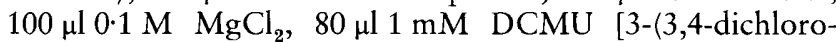
phenyl)-1,1-dimethylurea] in ethanol, $4 \mu \mathrm{l} 1 \mathrm{M}$ DTT, $133 \mu \mathrm{l} 1 \mathrm{M} \mathrm{NaN}_{3}, 10 \mu \mathrm{l} 1 \mathrm{M} \mathrm{L}$-ascorbic acid and $133 \mu \mathrm{l} 0.75 \%$ (w/v) CTAB (cetyltrimethylammonium bromide) were added and mixed thoroughly for $30 \mathrm{~s}$. After a 5 min incubation at $28^{\circ} \mathrm{C}$ under constant shaking, $40 \mu \mathrm{l} 10 \mathrm{mM}$ benzyl viologen and $10 \mu \mathrm{l} N, N, N^{\prime}, N^{\prime}$-tetramethyl-p-phenylenediamine were 
added and incubated for another $10 \mathrm{~min} ; 2 \mathrm{ml}$ of the suspension was transferred to the chamber of the oxygen electrode and oxygen consumption was recorded in the dark. Then, saturating actinic light $\left(3000 \mu \mathrm{mol} \mathrm{m}^{-2} \mathrm{~s}^{-1}\right)$ was supplied and the light-stimulated oxygen consumption was determined.

Epifluorescence microscopy. Epifluorescence microscopy was performed with a Zeiss Axioplan epifluorescence microscope equipped with a camera (MC100, Zeiss). Cells were stained with the 'LIVE/DEAD BacLight' bacterial viability kit (Molecular Probes) according to the manufacturer's instructions. Briefly, $1 \mu \mathrm{l}$ of each reagent A and B were diluted in $660 \mu \mathrm{l}$ PBS (137 $\mathrm{mM} \mathrm{NaCl}, 2 \cdot 7 \mathrm{mM} \mathrm{KCl}, 10 \cdot 1 \mathrm{mM} \mathrm{Na}_{2} \mathrm{HPO}_{4}$ and $1.8 \mathrm{mM}$ $\left.\mathrm{KH}_{2} \mathrm{PO}_{4}\right)$. Cells were harvested by centrifugation and $8 \times 10^{7}$ cells resuspended in $50 \mu \mathrm{l}$ of the dye solution. After $10 \mathrm{~min}$ incubation in the dark, $15 \mu$ l cell suspension was spread onto a microscope slide covered with a dried layer of $2 \%$ agarose that immobilized the cells. For simultaneous visualization of live and dead cells, the Zeiss 487909 filter combination $(450-490 \mathrm{~nm}$ excitation, $510 \mathrm{~nm}$ dichroic and $>520 \mathrm{~nm}$ emission filter) was used. DAPI staining of cells was performed according to Coleman (1980) and the stained cells were examined using the Zeiss 487901 filter combination $(365 \mathrm{~nm}$ exitation, $395 \mathrm{~nm}$ dichroic and $>397 \mathrm{~nm}$ emission filter), which allowed the simultaneous detection of the blue fluorescence from DAPI-stained chlorotic (non-autofluorescent) cells and the red autofluorescence of fully pigmented cells.

In vivo $\left[{ }^{35}\right.$ S]methionine labelling and two-dimensional gel electrophoresis. In vivo labelling of proteins in nitrogendepleted cells was performed by removing $8 \mathrm{ml}$ samples from nitrogen-deprived cultures into sterile $50 \mathrm{ml}$ Erlenmeyer flasks, the samples were supplied with $25 \mu \mathrm{Ci}\left[{ }^{35} \mathrm{~S}\right]$ methionine $(43.5 \mathrm{TBq})$ and incubated as before for the times indicated (see Fig. 6 legend). The cells were then chilled on ice, harvested by centrifugation, washed twice with ice-cold $80 \%$ actetone and resuspended in $120 \mu \mathrm{l}$ lysis buffer $[8 \mathrm{M}$ urea; $0.2 \%, \mathrm{v} / \mathrm{v}$, Triton X-100;2\%, w/v, DTT; $0.02 \%$, w/v, Pefablock (Boehringer Mannheim)]. Incorporation of $\left[{ }^{35}\right.$ S $]$ methionine into proteins was quantified by determining the radioactivity from a $10 \mu \mathrm{l}$ aliquot after precipitating proteins with $10 \%$ TCA. For each electrophoretic analysis, a sample volume corresponding to $0 \cdot 6 \times 10^{6} \mathrm{c}$.p.m. was loaded, unless otherwise indicated. Gel electrophoresis in two dimensions was carried out according to Görg et al. (1995). The first dimension was separated on $14 \mathrm{~cm}$ immobilized $\mathrm{pH}$ gradients (IPG dry strips, $\mathrm{pH}$ 4-7) using the multiphor flatbed electrophoresis system together with the immobiline dry strip kit (Pharmacia). The second-dimension gels were all run together on $16 \times 20 \times$ $0.1 \mathrm{~cm}$ Tricine SDS $10 \%$ acrylamide gels (Schägger \& van Jagow, 1987). Gels were silver stained (Blum et al., 1987), dried, exposed to phosphor screens (Molecular Dynamics) for 2-4 d and scanned with the PhosphorImager system (Molecular Dynamics) at $100 \mu \mathrm{m}$ resolution.

\section{RESULTS}

\section{Nitrogen-starvation-induced pigment degradation under different experimental conditions}

In previous reports, the time course and extent of PC and chl a loss that was observed upon depriving Synechococcus PCC 7942 cells of combined nitrogen varied considerably. Therefore, we examined the influence of different experimental conditions on pigment degradation. To precisely determine the onset of nitrogen deprivation, we intended to use cells in the exponential growth phase and resuspend them in nitrogen-deficient medium. We had previously observed that centrifugation caused a global distortion of cellular physiology, of protein synthesis patterns and of photosynthetic activities (J. Sauer, M. Görl \& K. Forchhammer, unpublished). For a minimal impact on cell physiology, cells were harvested by filtration through a $0.45 \mu \mathrm{m}$ PVDF filter in a transparent filtration unit, which allowed continued illumination during the procedure. Under these conditions, degradation of PC was nearly complete $24 \mathrm{~h}$ after nitrogen depletion (Fig. 1c, d), whereas cultures that were shifted by centrifugation still retained 40 to $50 \% \mathrm{PC}$ per culture volume (Fig. 1a, b). However, no significant influence of the shift procedure could be observed with respect to the chl a content of the culture (Fig. 1a, c). With both procedures, the $\mathrm{CO}_{2}$ supply was found to have a major influence on chl $a$ degradation; in the presence of $2 \% \mathrm{CO}_{2}$, chl a degradation was significantly retarded compared to cultures supplied with air $\left(0.03 \% \mathrm{CO}_{2}\right)$. The time course of the chlorotic response depended further on the PFD: PC degradation increased in parallel with the increase in light intensity and the chl $a$ content decreased even more rapidly at higher light intensities (data not shown).

\section{Long-term nitrogen-deprivation and survival of Synechococcus PCC 7942}

Synechococcus PCC 7942 cells were shifted to medium lacking combined nitrogen and were incubated under standard conditions $\left(2 \% \quad \mathrm{CO}_{2}, 50 \mu \mathrm{mol}\right.$ photons $\mathrm{s}^{-1} \mathrm{~m}^{-2}$ ) for up to $30 \mathrm{~d}$. At various times, aliquots were removed and analysed for $\mathrm{PC}, \mathrm{chl} a$ and glycogen. The $\mathrm{OD}_{750}$ was measured and numbers of c.f.u. after plating dilutions on nitrate-supplemented solid BG11 medium were also determined (Table 1). Based on the results of these experiments, three phases of the nitrogen-deprivation response could be defined. Phase 1 corresponded to the chlorotic response, which is characterized by a rapid decline of $\mathrm{PC}$ while the chl $a$ content of the culture only slightly decreased. The cells divided once and glycogen accumulated. Under our experimental conditions, this phase occupied the first $2 \mathrm{~d}$ of nitrogen deprivation. Phase 2 started when the PC degradation was complete. During phase 2, the chl a content of the culture decreased progressively, reaching nearly undetectable values; the carotenoid content also decreased during this phase (data not shown). The colour of the culture turned from yellowish-green to pale white during this phase, which lasted about $8-10 \mathrm{~d}$. The decay of the membrane-bound photosynthetic pigments was accompanied by a moderate reduction of the $\mathrm{OD}_{750}$ of the culture and by a decline in the numbers of c.f.u., whereas the glycogen content remained at a high level. Finally, the cells entered phase 3 , where no further changes in the appearance of the culture were observed. In phase 3, pigments were almost undetectable and the glycogen content remained at a high level. Surprisingly, the number of c.f.u. on nitrate-supplemented medium remained at a relatively low, but constant, level. However, a microscopic examination of the nitrogen-starved cells showed that cells tended to form aggregates which could 

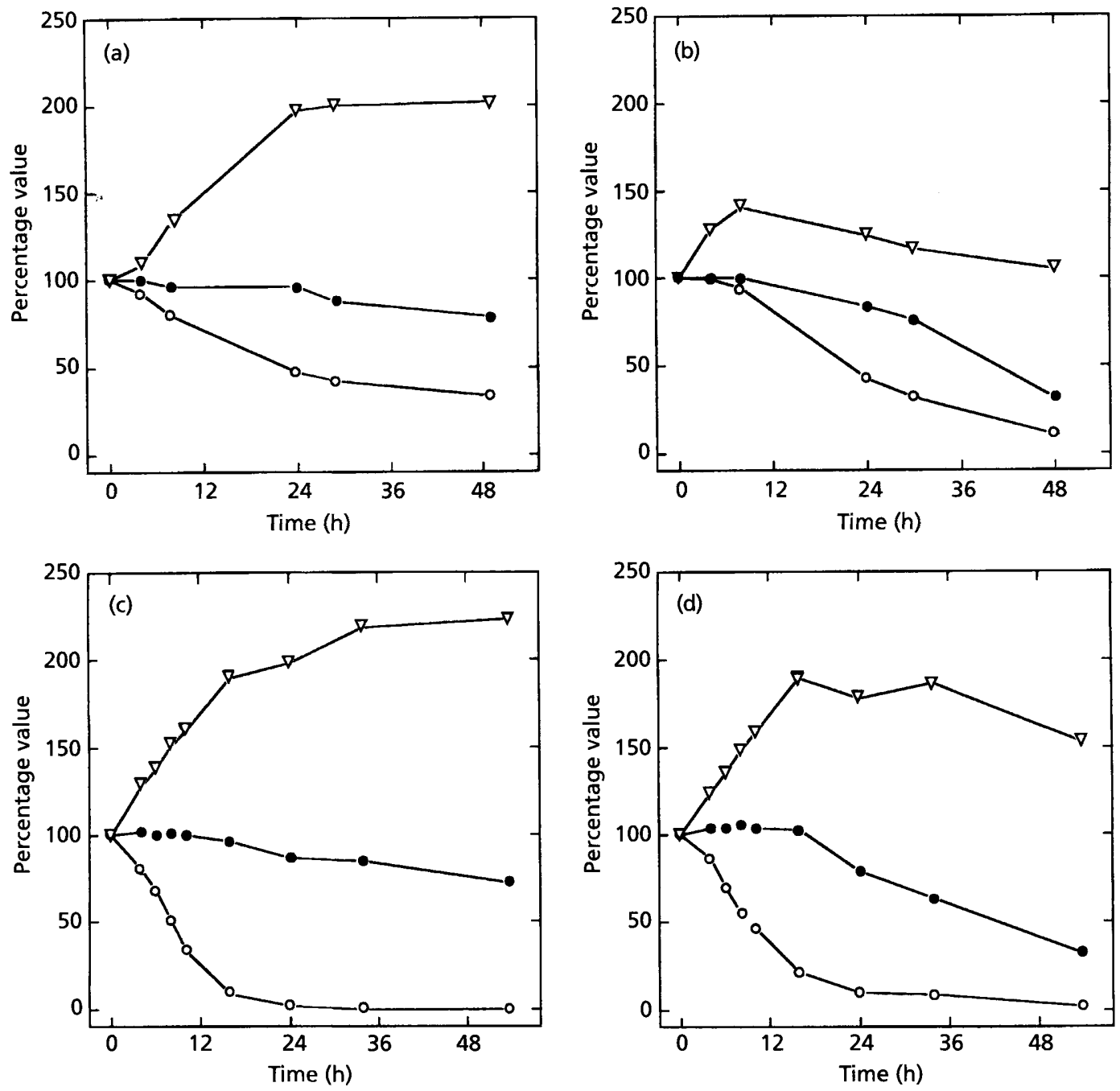

Fig. 1. Effect of experimental procedures initiating nitrogen deprivation and of the $\mathrm{CO}_{2}$ supply on the level of $P C$ and chl a per culture volume and $\mathrm{OD}_{750}$ of Synechococcus PCC 7942. The $100 \%$ values correspond to the values before the shift. Representative results are shown. $\nabla, \mathrm{OD}_{750} ; \mathrm{O}$, relative $\mathrm{PC}$ level ml $\mathrm{m}^{-1} ; \boldsymbol{0}$, relative chl a level ml $\mathbf{~}^{-1}$. Cells were shifted to nitrogen-deprived medium by centrifugation $(a, b)$ or by filtration $(c, d)$. Cultures were supplied with either $2 \% \mathrm{CO}_{2}$ in air $(a, c)$ or with air alone $(b, d)$. The absolute values corresponding to $100 \%$ were: PC, 0.1 net $A_{620} ; \mathrm{chl}^{a}, 1 \cdot 8 \mu \mathrm{g} \mathrm{ml}^{-1}$.

distort the determination of c.f.u. numbers. To more precisely examine the viability of long-term nitrogendeprived cultures, the cells were stained with the 'LIVE/DEAD BacLight' viability kit, which allows differentiation between living and dead cells on the basis of their membrane potential. By epifluorescence microscopy, dead cells show a red fluorescence whereas living cells fluoresce green. Cells from a culture starved for $1 \mathrm{~d}$ had already lost the typical cyanobacterial red autofluorescence and appeared green upon staining with 'LIVE/DEAD BacLight'. As a control for dead cells, an aliquot was boiled for $5 \mathrm{~min}$; these cells showed an orange-red fluorescence (Fig. 2a, b). The intensity of the green fluorescence faded in phase 2 cells and a small portion of red fluorescent cells became visible. Surprisingly, in samples of phase 3 cultures, almost all cells retained a green fluorescence (Fig. 2c), indicating that the cells still exhibited membrane potential. This result suggested that the majority of cells remained viable. Therefore, we developed a new method to analyse the regeneration potential of the nitrogen-deprived cells. Nitrogen-replete cyanobacteria display a red autofluorescence, which originates from PS II and phycobiliproteins. As a consequence of the degradation of photosynthetic pigments and of quenching effects (Collier et al., 1994), nitrogen-deprived cells rapidly lose their red autofluorescence. The reappearence of the autofluorescence after the addition of nitrate indicates the regeneration of their pigments. Since a small portion of viable cells could overgrow the culture during regeneration experiments, the antibiotic aztreonam, which specifically inhibits septum formation (Zambrano \& Kolter, 1996), was added to avoid this. At different times after the addition of nitrate and aztreonam to chlorotic cultures, aliquots were analysed by fluorescence microscopy. To allow the simultaneous visual- 
Table 1. Change in the levels of $P C, c h l$ a and glycogen, in $O D_{750}$ and in c.f.u. per culture volume during the course of nitrogen deprivation

The results are from one of three independent experiments and are expressed as percentages of the value before nitrogen step-down. The time course of the degradative processes in the different experiments varied by about $10 \%$ but proceeded in a similar manner. ND, Not done. The absolute values corresponding to $100 \%$ were: PC, 0.102 net $A_{620}$; chl $a, 1.8 \mu \mathrm{g} \mathrm{ml}^{-1}$; glycogen, $25 \mu \mathrm{g} \mathrm{ml}^{-1}$; $\mathrm{OD}_{750}, 0 \cdot 25$; c.f.u, $5 \cdot 2 \times 10^{7} \mathrm{ml}^{-1}$.

\begin{tabular}{|cccccc|}
\hline $\begin{array}{c}\text { N-deprivation } \\
(\text { d) }\end{array}$ & $\begin{array}{c}\text { Percentage } \\
\text { PC }^{*}\end{array}$ & $\begin{array}{c}\text { Percentage } \\
\text { chl } \boldsymbol{a}^{*}\end{array}$ & $\begin{array}{c}\text { Percentage } \\
\text { glycogen }\end{array}$ & $\begin{array}{c}\text { Percentage } \\
\text { OD }^{*}{ }^{*}\end{array}$ & $\begin{array}{c}\text { Percentage } \\
\text { c.f.u. }( \pm \text { SE })\end{array}$ \\
\hline 0 & 100 & 100 & 100 & 100 & 100 \\
1 & 5 & 87 & ND & 198 & ND \\
2 & 1 & 75 & 340 & 220 & $176 \pm 15$ \\
3 & 0 & 67 & 370 & 198 & $154 \pm 15$ \\
5 & 0 & 40 & 460 & 140 & $96 \pm 12$ \\
7 & 0 & 29 & 400 & 110 & $53 \pm 10$ \\
10 & 0 & 5 & 420 & 80 & $21 \pm 7$ \\
14 & 0 & $<1$ & 430 & 75 & $8 \pm 4$ \\
30 & 0 & $<1$ & 410 & 73 & $7 \pm 4$ \\
\hline
\end{tabular}

* The SE for the determination of $\mathrm{PC}, \mathrm{chl} a$, glycogen and $\mathrm{OD}_{750}$ in a single experiment was below $5 \%$.

ization of the non-regenerated cells, the samples were counter-stained with the blue fluorescent dye DAPI. Fig. 3 shows a typical experiment with cells that had been nitrogen-depleted for $20 \mathrm{~d}$. In different experiments, about $5-10 \%$ of the cells recovered the red autofluorescence within the first $2 \mathrm{~d}$. Following a lag phase of another 2-3 d with no siginificant increase of regeneration, nearly all cells regained red autofluorescence after a total regeneration time of $4-5 \mathrm{~d}$.

\section{Photosynthetic activities during nitrogen deprivation}

To define any relationship between nitrogen deprivation and photosynthesis, we assayed photosynthesis-related activities during chlorosis. At various times following nitrogen depletion, light-dependent oxygen exchange was assayed in the dark and at several PFDs to estimate dark respiration, quantum efficiency and $V_{\max }$ of complete photosynthesis. In cells that were shifted to nitratedeprived medium, a rapid decline in photosynthetic capacity was observed (Fig. 4a). Six hours after the shift, a $50 \%$ decline in $V_{\max }$ became evident and after $24 \mathrm{~h}$, the quantum yield decayed strongly as evidenced by the decreased slope of the light-dependent region. Photosynthetic oxygen evolution vanished almost completely after $72 \mathrm{~h}$. PS II activity was determined at saturating light $\left(3000 \mu \mathrm{mol} \mathrm{s}^{-1} \mathrm{~m}^{-2}\right)$ using the Hill reaction (Fig. $4 \mathrm{~b})$. PS II activity followed the decline of $V_{\max }$ with some delay (Fig. 4b). PS I activity was measured as lightinduced oxygen uptake (Mehler reaction) in cells in which PS II activity was inhibited by DCMU (Hauska, 1980) (Fig. 5). Although this method only allows a rough estimate of PS I activity, it is evident that PS I activity decays much more slowly than light-dependent oxygen evolution or PS II activity. Only after $4 \mathrm{~d}$ of nitrogen starvation was a decay of PS I activity apparent, which paralleled the degradation of chl $a$. PS I activity was undetectable after $16 \mathrm{~d}$ of nitrogen starvation.

\section{Protein synthesis in nitrogen-deprived cells}

To obtain a preliminary insight into global changes of gene expression associated with nitrogen deprivation, we investigated the protein composition and new protein synthesis during the different phases of nitrogen starvation using two-dimensional gel electrophoresis. At various times following nitrogen deprivation, aliquots were removed from the chlorotic cultures and labelled with $\left[{ }^{35} \mathrm{~S}\right]$ methionine. Subsequently, cell extracts were analysed by electrophoresis (Fig. 6). About $5 \mathrm{~h}$ after the shift to nitrogen-deprived medium, the synthesis of a multitude of proteins appeared to be affected, when compared to the synthesis pattern of nitrogen-replete cells. Computer-assisted evaluation of the autoradiograms identified at least 70 proteins that were strongly induced and about 50 which decreased in intensity, following nitrogen deprivation (data not shown). The protein synthesis pattern of cells in phase 2 showed a significant reduction of the number of spots. Interestingly, several spots appeared only after long-term starvation (some representatives are indicated by rectangles in Fig. 6). In phase 3, the labelling efficiency decreased dramatically. Only very few proteins could be identified which were synthesized under these conditions. Similar to the labelling patterns, the silverstained gels showed a strong reduction of the protein inventory during phase 2 of chlorosis, reaching a minimal protein composition in the phase 3 cells (data not shown). 

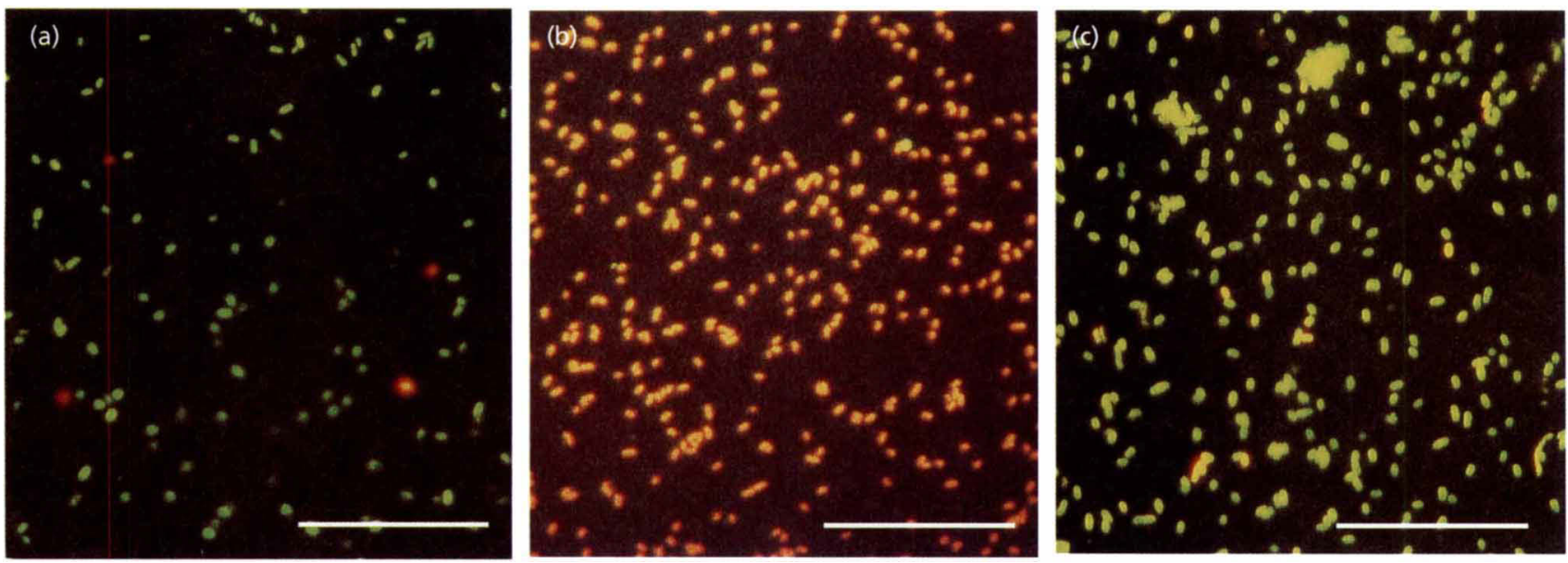

Fig. 2. Epifluorescence microscopy of Synechococcus PCC 7942 cells after staining with the 'LIVE/DEAD BacLight' viability kit. (a) Cells after $1 \mathrm{~d}$ nitrogen deprivation; (b) the same cells after boiling for $5 \mathrm{~min}$; (c) cells after $28 \mathrm{~d}$ nitrogen deprivation. Bar, $10 \mu \mathrm{m}$.
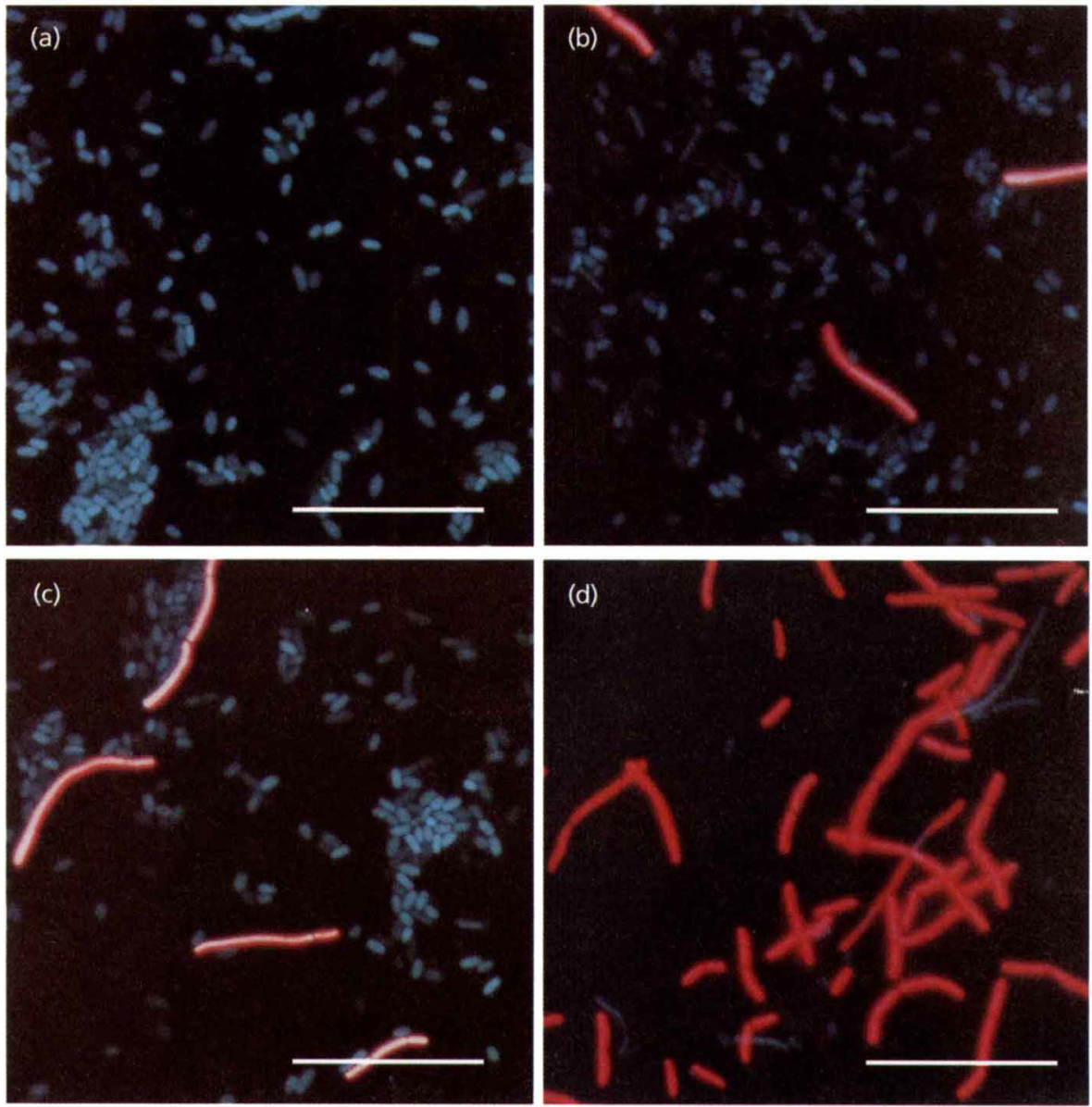

Fig. 3. Regeneration of nitrogen-deprived Synechococcus PCC 7942 cells visualized by epifluorescence microscopy. Cells that had been starved for nitrogen for $20 \mathrm{~d}$ were regenerated by the addition of nitrate in the presence of aztreonam; aliquots were removed at various times, stained with DAPI and analysed by epifluorescence microscopy. Regenerated cells display a bright-red autofluorescence, whereas chlorotic cells show the blue DAPI fluorescence. (a) Before the addition of nitrate, (b) $2 \mathrm{~d}$, (c) $3 \mathrm{~d}$, (d) $4 \mathrm{~d}$ after the addition of nitrate. Bar, $10 \mu \mathrm{m}$. 

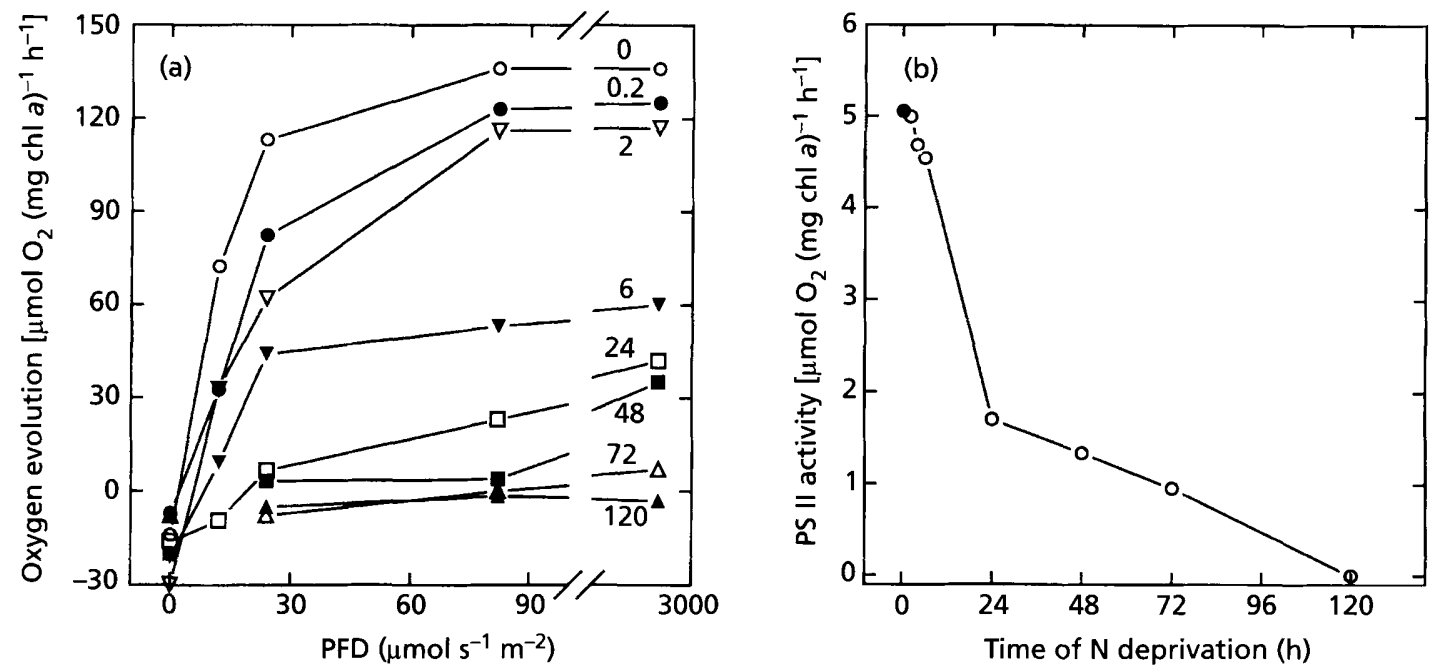

Fig. 4. (a) Photosynthetic oxygen evolution of Synechococcus cells at increasing PFDs after $0,0 \cdot 2,2,6,24,48,72$ and $120 \mathrm{~h}$ of nitrogen starvation. (b) PS II activity was determined at saturating light intensity by the use of the Hill reaction from the same cultures as those in (a).

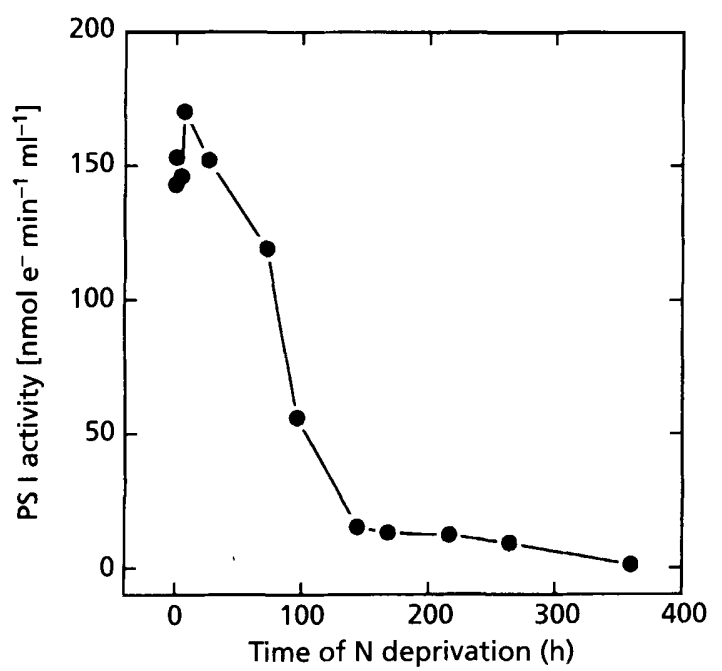

Fig. 5. PS I activity measured as light-induced oxygen uptake (Mehler reaction) in permeabilized cells after nitrogen deprivation.

\section{DISCUSSION}

We have presented evidence that depletion of the nondiazotrophic cyanobacterium Synechococcus PCC 7942 for combined nitrogen causes a differentiation process that enables the cells to survive long periods of starvation. Based on the temporal sequence of adaptive responses, this differentiation process can be divided into three phases, reminescent of three stages of the starvation-survival process described in heterotrophic bacteria (Morita, 1993). In the nitrogen-starvation response of Synechococcus PCC 7942, these phases are characterized by the following events. In phase 1 , the cells divide once, while the phycobiliproteins are de- graded to near completion. Photosynthetic oxygen evolution decayed after $1 \mathrm{~d}$ of nitrogen deprivation, as previously reported (Allen et al., 1990); PS I activity remained unaffected during this time (Collier et al., 1994). The decay of the $V_{\max }$ of photosynthesis preceded the decay of PS II activity. This result implies that the reduction of photosynthetic electron transport is caused by an impairment in the metabolic reactions linked to photosynthesis. Since no nitrogen is available to the cells for synthesis of nitrogen-containing metabolites, the flow of photosynthate is channelled into glycogen synthesis. Indeed, Coronil et al. (1993) showed that immediately after nitrogen depletion, Synechococcus cells reduce the flow of newly fixed $\mathrm{CO}_{2}$ into the amino acid pool. Therefore, the amino acids for new protein synthesis must originate from protein turnover, most prominently from phycobiliprotein degradation. Of the about 70 starvation-induced spots that could be visualized by two-dimensional gel electrophoresis of pulselabelled cells, some are specific for nitrogen depletion but others also appear under conditions of sulfur deprivation (J. Sauer \& K. Forchhammer, unpublished). In addition to the reduction in the synthesis of the phycobiliproteins by nitrogen starvation, an effect previously demonstrated by Lau et al. (1977), the synthesis of a variety of other proteins was also strongly inhibited. Factors involved in sensing nutrient starvation in cyanobacteria have not yet been identified at the molecular level. The signal-transduction protein $\mathrm{P}_{\mathrm{II}}$ might be required in responses specific for nitrogen deprivation, since its phosphorylation state is maximal under conditions of nitrogen deprivation (Forchhammer \& Tandeau de Marsac, 1995). Whether $\mathrm{P}_{\mathrm{II}}$ is indeed involved in the nitrogen deprivation response is currently under investigation. In phase 1 , cells can quickly regenerate after the addition of a combined nitrogen source (Allen, 1984). The resynthesis of phycobiliproteins has been 
(a)

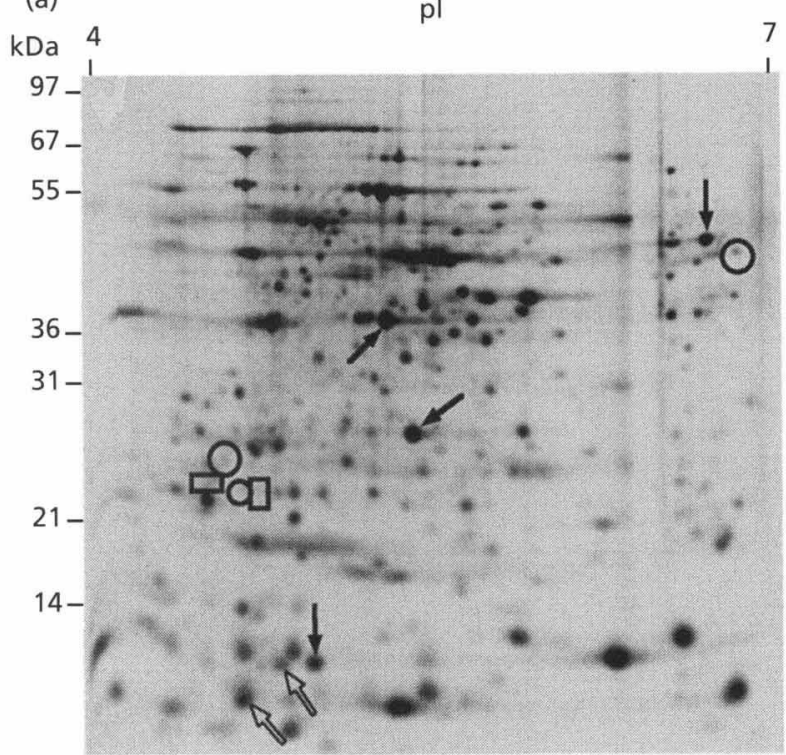

(c)

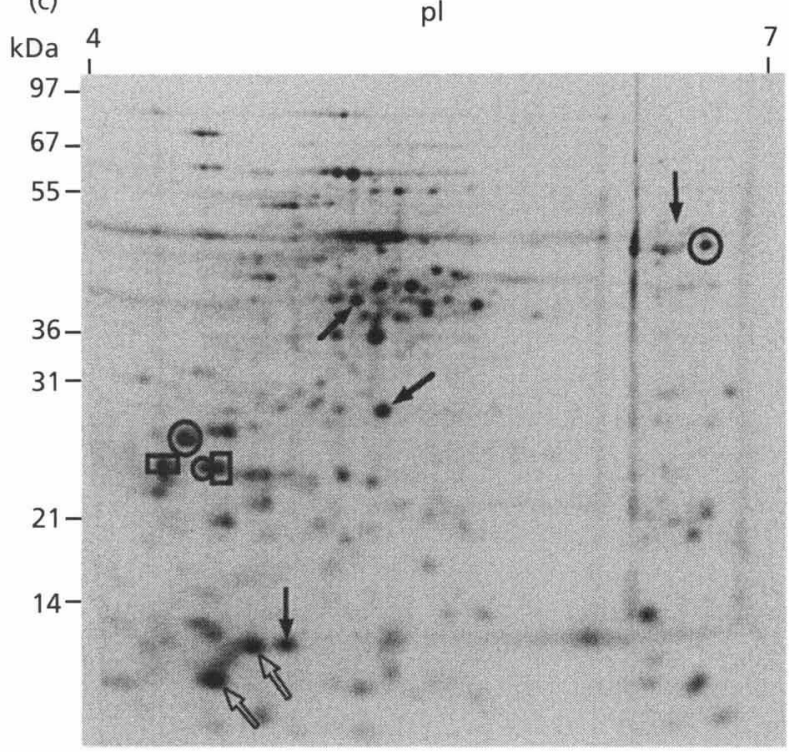

(b)

$\mathrm{kDa}$

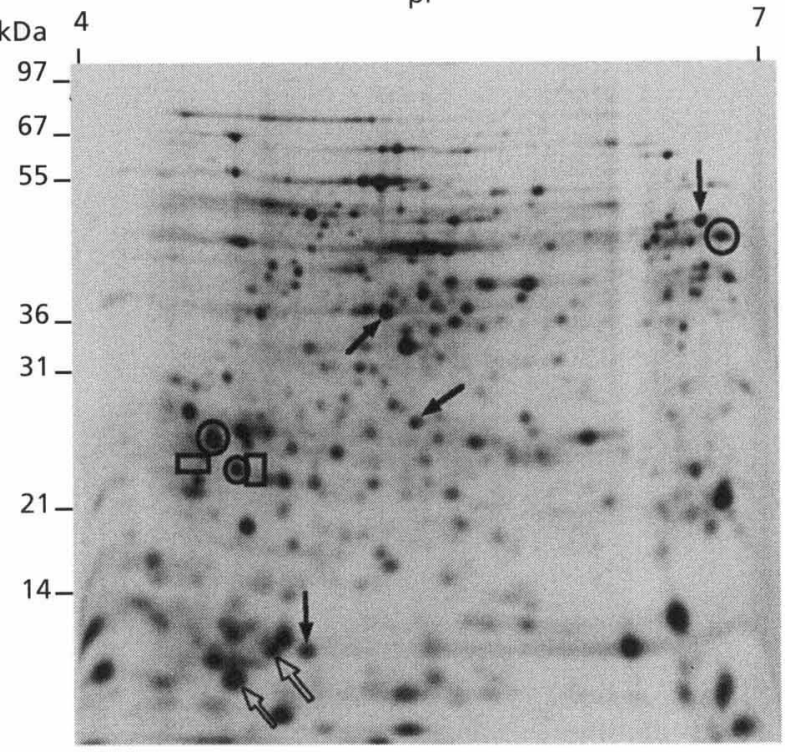

(d)

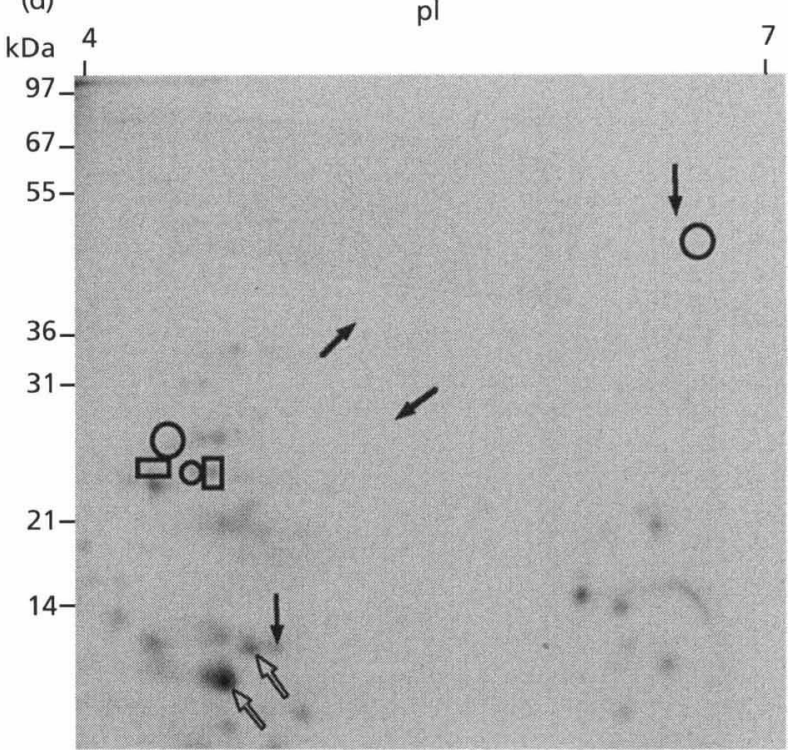

Fig. 6. Protein synthesis patterns of Synechococcus PCC 7942 cells during different phases of nitrogen starvation as revealed by in vivo ${ }^{35} \mathrm{~S}$ ]methionine labelling and two-dimensional gel electrophoresis. (a) Cells from a nitrogen-replete culture were labelled for $90 \mathrm{~min}$. (b-d) Nitrogen-starved cells were labelled (b) in phase 1 (4 h after nitrogen step-down for $90 \mathrm{~min}$ ); (c) in phase 2 (4 d after nitrogen step-down for $24 \mathrm{~h}$ ) and (d) in phase 3 (15 d after nitrogen step-down for $3 \mathrm{~d}$ ). Due to the low labelling efficiency of phase 3 cells, only 150000 c.p.m. could be loaded on the gel shown in (d). To facilitate a comparison between the gels, some landmarks are indicated. The black arrows point to some proteins which are synthesized in nitrogen-replete cells and which gradually disappear during phase 2 or phase 3 . The white arrows indicate proteins which are constantly synthesized under all conditions. The circles enclose some selected spots which first appear in phase 1 and the squares enclose spots which appear in phase 2.

suggested to be controlled at the level of transcription by the chromophore supply (Gilbert et al., 1996).

Prolonged nitrogen depletion causes Synechococcus PCC 7942 cells to differentiate further into a nonphotosynthetic state. At the beginning of phase 2, PS II is already inactive but the cells can still generate ATP by PS I activity. The fact that most cyanobacterial chl $a$ is associated with PS I (Manodori et al., 1984; Bryant
1986) implies that chl $a$ degradation reflects the loss of PS I reaction centres. Concomitantly, a breakdown of the photosynthetic membranes, the thylakoids, can be visualized in these cells by electron microscopy (Wanner et al., 1986; G. Wanner, A. Bock \& K. Forchhammer, unpublished). At the same time, the protein content of the cells decreases greatly, most likely by proteolytic processes. New protein synthesis still takes place, although at a reduced level, as deduced from the long 
labelling period required to achieve sufficient incorporation of $\left.{ }^{35} \mathrm{~S}\right]$ methionine. The synthesis pattern indicates an extensive alteration of gene expression. In a variety of bacteria, gene expression in stationary phase is altered due to the activity of specific sigma factors (Hengge-Aronis, 1993; Antelmann et al., 1997). In the genomic sequence of the unicellular cyanobacterium Synechocystis PCC 6803, at least eight genes encoding putative sigma factors have been found (Kaneko et al., 1996) and in the marine cyanobacterium Synechococcus PCC 7002, the presence of at least five sigma factors has been demonstrated, two of which are expressed under conditions of carbon and nitrogen starvation (Caslake $e t$ al., 1997). Whether a special sigma factor operates in the nitrogen-deprivation response of Synechococcus PCC 7942 remains to be demonstrated.

After completion of the degradative processes, Synechococcus cells enter phase 3 of chlorosis, which exhibits features of a dormant state. This contrasts with the stationary-phase physiology in various heterotrophic bacteria, where under prolonged starvation the number of surviving cells initially decreases exponentially and finally stabilizes at a low level. Such cultures are in a dynamic equilibrium between growth and death (Kolter, 1992). A dormant-like state in Synechococcus PCC 7942 is deduced from the following observations. (i) No photosynthetic activities could be measured in longterm starved cells. Although it is tempting to speculate that these chlorotic cells maintain a very low PS I activity that could energize the cells by cyclic electron transport, the method employed in our investigation was not sensitive enough to detect very low PS I activities after long-term-starvation periods. (ii) Respiration was abolished and the glycogen reserves were not utilized, indicating that they did not contribute to the energy supply of the cells. (iii) Only traces of protein synthesis could be detected, which was limited to a minor subset of proteins. If a small number of survivors were to live on lysis products, one would expect a protein synthesis pattern resembling that of growing cells. (iv) Analysis of single-cell viability suggested that the majority of cells maintained membrane potential and retained the capacity to regenerate in liquid medium. In contrast, regeneration on solid media yielded low counts of viable cells. This resembles the 'viable but non-culturable' state, a term that is used when starved but viable cells fail to yield colonies on solid regeneration medium (discussed by Bloomfield et al., 1998). The molecular basis of the dormant state and of the regeneration processes merits further investigations. The capacity of Synechococcus PCC 7942 cells to sustain prolonged starvation periods could represent an important mechanism for cyanobacterial populations to survive in natural environments.

\section{ACKNOWLEDGEMENTS}

We thank B. A Bmus for help with the 'LIVE/DEAD BacLight' and A. Hedler for technical assistance. We are grateful to J. C.. Meeks and A. Ernst for helpful discussion and for improving the manuscript, and to A. Böck for constant encouragement.
This work was supported by a grant from the Deutsche Forschungsgemeinschaft.

\section{REFERENCES}

Allen, M. M. (1984). Cyanobacterial cell inclusions. Annu Rev Microbiol 38, 1-25.

Allen, M. M. \& Smith, A. J. (1969). Nitrogen chlorosis in bluegreen algae. Arch Microbiol 69, 114-120.

Allen, M. M., Law, A. \& Evans, E. H. (1990). Control of photosynthesis during nitrogen depletion and recovery in a nonnitrogen-fixing cyanobacterium. Arch Microbiol 153, 428-431.

Antelmann, H., Engelmann, S., Schmid, R., Sorokin, A., Lapidus, A. \& Hecker, M. (1997). Expression of a stress- and starvationinduced $d p s /$ pex $B$-homologous gene is controlled by the alternate sigma factor sigma(B) in Bacillus subtilis. $J$ Bacteriol 179, 7251-7256.

Bloomfield, S. F., Stewart, G. S. A. B., Dodd, C. E. R., Booth, I. R. \& Power, E. G. M. (1998). The viable but non-culturable phenomenon explained? Microbiology 144, 1-2.

Blum, H., Beier, H. \& Gross, H. J. (1987). Improved silver staining of plant proteins, RNA and DNA in polyacrylamide gels. Electrophoresis 8, 93-99.

Bryant, D. A. (1986). The cyanobacterial photosynthetic apparatus: comparisons to those of higher plants and photosynthetic bacteria. Can Bull Fish Aquat Sci 214, 423-500.

Caslake, L. F., Gruber, T. M. \& Bryant, D. A. (1997). Expression of two alternative sigma factors of Synechococcus sp. strain PCC 7002 is modulated by carbon and nitrogen stress. Microbiology 143, 3807-3818.

Coleman, A. W. (1980). Enhanced detection of bacteria in natural environments by fluorochrome staining of DNA. Limnol Oceanogr 25, 948-951.

Collier, J. L. \& Grossman, A. R. (1992). Chlorosis induced by nutrient deprivation in Synechococcus sp. strain PCC 7942: not all bleaching is the same. J Bacteriol 174, 4718-4726.

Collier, J. L. \& Grossman, A. R. (1994). A small polypeptide triggers complete degradation of light-harvesting phycobiliproteins in nutrient-deprived cyanobacteria. EMBO J 13, 10391047.

Collier, J. L., Herbert, S. K., Fork, D. C. \& Grossman, A. R. (1994). Changes in the cyanobacterial photosynthetic apparatus during acclimation to macronutrient deprivation. Photosynth Res 42, $17.3-18.3$.

Coronil, T., Lara, C. \& Guerrero, M. G. (1993). Shift in carbon flow and stimulation of amino acid turnover induced by nitrate and ammonium assimilation in Anacystis nidulans. Planta 189, 461-467.

Forchhammer, K. \& Tandeau de Marsac, N. (1995). Functional analysis of the phosphoprotein $\mathrm{P}_{\mathrm{II}}(\mathrm{g} \ln B$ gene product) in the cyanobacterium Synechococcus sp. strain PCC 7942. J Bacteriol 177, 2033-2040.

Gilbert, S. M., Allison, G. G., Rogers, L. L. \& Smith, A. J. (1996). Expression of genes involved in phycocyanin biosynthesis following recovery of Synechococcus PCC 6301 from nitrogen starvation, and the effect of gabaculine on $c p c B A$ transcript levels. FEMS Microbiol Lett 140, 93-98.

Görg, A., Boguth, G., Obermaier, C., Posch, A. \& Weiss, W. (1995). Two-dimensional polyacrylamide gel electrophoresis with immo- 
bilized $\mathrm{pH}$ gradients in the first dimension (IPG-Dalt): the state of the art and the controversy of vertical versus horizontal systems. Electrophoresis 16, 1079-1086.

Grossman, A. R., Schaefer, M. R., Chiang, G. G. \& Collier, J. L. (1994). The responses of cyanobacteria to environmental conditions: light and nutrients. In The Molecular Biology of Cyanobacteria, pp. 641-675. Edited by D. A. Bryant. Dordrecht: Kluwer.

Hauska, G. (1980). Measurement of phosphorylation associated with photosystem I. Methods Enzymol 69, 648-658.

Hengge-Aronis, R. (1993). Survival of hunger and stress: the role of $r p o S$ in early stationary phase gene regulation in E. coli. Cell 72, 165-168.

Kaneko, T., Sato, S., Kotani, H. \& 21 other authors (1996). Sequence analysis of the genome of the unicellular cyanobacterium Synechocystis sp. strain PCC 6803. II. Sequence determination of the entire genome and assignement of potential protein-coding regions. DNA Res 3, 109-136.

Kolter, R. (1992). Life and death in stationary phase. ASM News 58, 75-79.

Kuhlemeier, C. J., Thomas, A. A. M., van der Ende, A., van Leen, R. W., Borrias, W. E., van den Hondel, C. A. \& van Arkel, G. A. (1983). A host-vector system for gene cloning in the cyanobacterium Anacystis nidulans R2. Plasmid 10, 156-163.

Lau, R. H., MacKenzie, M. M. \& Doolittle, W. F. (1977). Phycocyanin synthesis and degradation in the blue-green bacterium Anacystis nidulans. J Bacteriol 132, 771-778.

Manodori, A., Alhadeff, M., Glazer, A. N. \& Melis, A. (1984). Photochemical apparatus organization in Synechococcus 6301 (Anacystis nidulans). Effect of phycobilisome mutation. Arch Microbiol 139, 117-123.
Miyake, M., Kataoka, K., Shirai, M. \& Asada, Y. (1997). Control of poly- $\beta$-hydroxybutyrate synthase mediated by acetyl phosphate in cyanobacteria. J Bacteriol 179, 5009-5013.

Morita, R. Y. (1993). Bioavailability of energy and the starvation state. In Starvation in Bacteria, pp. 1-23. Edited by S. Kjelleberg. New York: Plenum.

Rippka, R. (1988). Isolation and purification of cyanobacteria. Methods Enzymol 167, 3-27.

Schägger, H. \& van Jagow, G. (1987). Tricine-sodium dodecylsulfate-polyacrylamide electrophoresis for the separation of proteins in the range from 1 to $100 \mathrm{kDa}$. Anal Biochem 166, 369-379.

Shen, G., Boussiba, S. \& Vermaas, W. F. (1993). Synechocystis sp. PCC 6803 strains lacking photosystem I and phycobilisome function. Plant Cell 5, 1853-1863.

Tandeau de Marsac, N. \& Houmard, J. (1993). Adaptation of cyanobacteria to environmental stimuli: new steps towards molecular mechanisms. FEMS Microbiol Rev 104, 119-190.

Walker, D. (1987). The Use of the Oxygen Electrode and Fluorescence Probes in Simple Measurements of Photosynthesis. Sheffield, UK: Oxygraphics.

Wanner, G., Henkelmann, G., Schmidt, A. \& Köst, H. P. (1986). Nitrogen and sulfur starvation of the cyanobacterium Synechococcus 6301. Z Naturforsch 41c, 741-750.

Watson, S.P., Clements, M. O. \& Foster, S. J. (1998). Characterization of the starvation-survival response of Staphylococcus aureus. J Bacteriol 180, 1750-1758.

Zambrano, M. M. \& Kolter, R. (1996). GASPing for life in stationary phase. Cell $\mathbf{8 6}, 181-184$.

Received 22 December 1997; revised 4 May 1998; accepted 18 May 1998. 